\title{
Down syndrome, accelerated aging and immunosenescence
}

\author{
Noémie Gensous ${ }^{1,2,3}$ (D) Maria Giulia Bacalini ${ }^{4}$. Claudio Franceschi ${ }^{1,4,5} \cdot$ Paolo Garagnani ${ }^{1,6,7,8}$
}

Received: 8 April 2020 / Accepted: 29 June 2020 / Published online: 23 July 2020

(C) The Author(s) 2020

\begin{abstract}
Down syndrome is the most common chromosomal disorder, associated with moderate to severe intellectual disability. While life expectancy of Down syndrome population has greatly increased over the last decades, mortality rates are still high and subjects are facing prematurely a phenomenon of atypical and accelerated aging. The presence of an immune impairment in Down syndrome subjects is suggested for a long time by the existence of an increased incidence of infections, the incomplete efficacy of vaccinations, and a high prevalence of autoimmunity. Immunologic abnormalities have been described since many years in this population, both from a numerical and a functional points of view, and these abnormalities can mirror the ones observed during normal aging. In this review, we summarize our knowledge on immunologic disturbances commonly observed in subjects with Down syndrome, and in innate and adaptive immunity, as well as regarding chronic inflammation. We then discuss the role of accelerated aging in these observed abnormalities and finally review the potential age-associated molecular and cellular mechanisms involved.
\end{abstract}

Keywords Down syndrome $\cdot$ Accelerated aging $\cdot$ Immunosenescence $\cdot$ Inflammaging

\section{Introduction}

Down syndrome (DS) or trisomy 21 is the most common known genetic disorder associated with moderate to severe intellectual disability, occurring in approximately 1 out of every $600-700$ live births $[1,2]$. DS is related to a chromosomal disorder, corresponding to a total or partial trisomy of the autosomal chromosome 21. Even if during the past decades life expectancy in DS population has greatly increased [3-6],
DS individuals have still higher mortality rates as compared with other populations [7, 8]. In addition to signs specifically associated with their congenital syndrome, subjects with DS appear to age differently from the general population, and it is evident that they present symptoms of aging ahead of time, leading to the classical description of DS as a progeroid syndrome and as a model of accelerated aging [9-12].

In this work, we review how the phenomenon of aging impacts the immune system in DS subjects. We firstly

This article is a contribution to the special issue on: Immunosenescence: New Biomedical Perspectives - Guest Editors: Claudio Franceschi, Aurelia Santoro, and Miriam Capri

Noémie Gensous

noemie_gensous@hotmail.com; noemieelise.gensous2@unibo.it

1 Department of Experimental, Diagnostic and Specialty Medicine, Alma Mater Studiorum, University of Bologna, 40138 Bologna, Italy

2 ImmunoConcEpT CNRS UMR 5164, University of Bordeaux, Bordeaux, France

3 Department of Internal Medicine and Clinical Immunology, CHU Bordeaux (Groupe Hospitalier Saint-André), 33076 Bordeaux, France

4 IRCCS Istituto delle Scienze Neurologiche di Bologna, 40139 Bologna, Italy
5 Laboratory of Systems Medicine of Healthy Aging and Department of Applied Mathematics, Lobachevsky University, Nizhny Novgorod 603950, Russia

6 Department of Laboratory Medicine, Clinical Chemistry, Karolinska Institutet, Karolinska University Hospital, 171

76 Stockholm, Sweden

7 Applied Biomedical Research Center (CRBA), Policlinico S. Orsola-Malpighi Polyclinic, 40138 Bologna, Italy

8 CNR Institute of Molecular Genetics "Luigi Luca Cavalli-Sforza," Unit of Bologna, 40136 Bologna, Italy 
describe clinical features of DS individuals from an immune point of view. We then summarize evidence on immunosenescence in DS subjects and how it impacts both innate and adaptive immunity, as well as chronic inflammation. Finally, we discuss the potentially age-associated mechanisms involved.

\section{Accelerated and atypical aging in Down syndrome}

DS has long been considered as a progeroid syndrome, as individuals with trisomy 21 start to age prematurely and present precociously conditions usually characteristic of the geriatric population [9-12]. The aging process in DS subjects not only seems to be premature/accelerated but also appears to be atypical and segmental, as it recapitulates many, but not all, of the classical signs and symptoms of aging [13, 14]. Clinically, DS subjects present signs of early aging affecting particularly the neurological system, with an extremely high prevalence of dementia of Alzheimer's type [15]. Aging affects also prematurely the dermatological, sensory, endocrine, and musculoskeletal systems, leading to high levels of mortality and multimorbidity in this population [16].

From a biological point of view, the same trend of accelerated aging has been observed with the use of aging biomarkers [17]. The latest and powerful generations of biomarkers which are based on different approaches have been applied to cohorts of DS adults. Interestingly, these different biomarkers show concordantly accelerated aging in subjects with DS, whether epigenetic clocks [18, 19], metabolic biomarkers such as GlycoAge [20], or predicted brain age [21] are tested.

\section{Clinical features suggesting an immune impairment in Down syndrome individuals}

Significant evidence has accumulated on the existence of an immune dysregulation in DS, existing from the very beginning of the life of DS individuals. Firstly, it has been observed that DS subjects are characterized by a higher susceptibility to bacterial infections as compared with the general population, with especially a higher incidence of recurrent and chronic respiratory tract ones [22-25]. DS individuals have furthermore altered responses to vaccinations with conjugate or toxoid vaccines [26-29]. These suboptimal antibody responses potentially worsen the phenomenon of higher susceptibility to infections. Finally, DS subjects have frequently high levels of autoantibodies. While some of them seem to be not related to an eventual clinical significance [30], the others are associated with a higher incidence of organ-specific autoimmune disorders, affecting especially the endocrine system [31-33].
This clinical picture recapitulates the increased incidence of infections, the failure of vaccination, and the high prevalence of autoantibodies that can be observed in older people of the general population, supporting here also the concept of DS as an accelerated aging syndrome. This clinical presentation is the reflect of important alterations in immune homeostasis in DS with significant perturbations in all branches of the immune system, some of them being common with the ones observed during immunosenescence and that will be detailed in the next sections.

\section{Immunosenescence and inflammaging in Down syndrome}

During aging, the immune system shows marked changes which have been gathered under the term immunosenescence [34-37]. There is a progressive decline in several immune parameters, affecting both innate and acquired immunity, as compared with young healthy subjects. Main hallmarks of immunosenescence are a reduction in the output of naive $T$ cells by the thymus with an accumulation of memory cells and a consequent reduction in the $\mathrm{T}$ cell repertoire and in the ability of these cells to respond to novel antigens (whether infectious or vaccinations). Alongside, aging is characterized by the existence of a chronic, sterile, low-grade inflammation named inflammaging [38]. In the next paragraphs, we will try to parallel the observations made on DS subjects' immune system and the ones observed during normal aging, focusing on adaptive immunity, innate immunity, and inflammation.

\section{Adaptive immune system}

The main changes in the adaptive immune system during normal aging occur in the $\mathrm{T}$ cell compartment as $\mathrm{T}$ lymphocytes appear to be dramatically affected, with a decrease in naïve $\mathrm{T}$ cells and an increase in memory ones [37,39-41]. The decline in the maintenance of a sizable naïve $T$ cell compartment leads to a major restriction in $\mathrm{T}$ cell diversity with increasing age $[42,43]$. This restricted $\mathrm{T}$ cell repertoire correlates with the inability to mount efficient immune responses to novel antigens. Additionally, changes in the distribution of memory $\mathrm{T}$ cell subpopulations are observed during aging. Immunosenescence is characterized by the accumulation of effector memory $\mathrm{T}$ cells (TEM) and T effector memory reexpressing CD45RA cells (TEMRA) (defined as CCR7CD45RA- and CCR7-CD45RA+ respectively), while there is a decrease in central memory T cell (TCM) compartment (defined as CCR7+CD45RA-). The accumulation of terminally differentiated cells with a senescent phenotype during aging has also been more recently associated with the expression of other surface markers, such as CD57, KLRG1, and 
PD-1 [44]. KLRG1 is considered as an inhibitor of proliferation, whereas PD-1 is associated with immune exhaustion.

In DS, studies on immune system have been mainly focused on the T cell compartment (Table 1). DS subjects seem to have a clear reduction in the number of circulating CD4+ T cells as compared with age-matched controls [45-51]. Beyond this numerical reduction of CD4+ T cells, an impaired maturation has also been observed [52] and imbalances between $\mathrm{T}$ cell subpopulations have been described [23, 45, 49, 53-55]. Like during immunosenescence, a reduction in naïve (CD4+ CD45RA+) lymphocytes has been described in DS, as well as an enrichment in memory $\mathrm{T}$ cells and a progressive inversion of the CD4+/CD8+ ratio [45-47, 56]. Higher percentages of Th1 and Th17 lymphocytes have been observed in subjects with DS, while there was no difference in Th2 cell percentages, suggesting a discrete imbalance between proinflammatory and anti-inflammatory immune responses [49, 57]. Regarding peripheral regulatory $T$ cells, their proportions are increased, but their function seems to be impaired, as their inhibitory activity is decreased as compared with controls [49, $53,57,58]$. Functional impairment of other T cell subpopulations has also been described, supported by weaker proliferative responses to specific mitogens at all ages [51, 59-62] and imbalanced cytokine production [58, 60, 63]. However, recently, Schoch et al. stated that despite phenotypical signs of immune exhaustion of lymphocyte subsets (quantified by a higher expression of PD-1), their functionality was normal and preserved, as the subjects were able to mount effector $\mathrm{T}$ cell responses with normal functional characteristics [49]. Finally, regarding CD8+ T cells, they appear to also be depleted in naïve subsets, with a higher expression of markers of activation (granzyme B, interferon-gamma, and tumor necrosis factor-alpha) and senescence (KLRG1) [57].

The thymus is a key lymphoid organ affected by immunosenescence, as it undergoes major changes during aging with a process of involution and shrinking, and a constant decline in the output of newly generated T lymphocytes [39]. In DS subjects, numerous reports have described thymic impairment, with reduced thymic size, decreased intra-thymic expansion of immature $\mathrm{T}$ cells, alterations in thymocyte subpopulations, and inefficient intra-thymic maturation [64-69]. $\mathrm{T}$ cell receptor (TCR) rearrangement excision circle (TREC) counts can be used to estimate recent thymic lymphocyte emigrants, a reflection of the newly generated $\mathrm{T}$ cells. In DS, numbers of TREC+ peripheral blood cells are significantly lower than those in healthy controls, possibly accelerating the early senescence of the immune system, with a negative correlation between age and the levels of TREC+ cells [48, 58, 69].

Aging also affects the humoral compartment, with reduction in B cell numbers and repertoire diversity [70]. In DS, there are lower numbers of circulating B cells as compared with controls [47, 49, 50, 56, 63, 71], with associated changes in B cell subpopulations (Table 2). Thus, defects in memory B cells have been described [29, 48, 71-73] but also decrease in transitional and/or naïve B lymphocytes $[56,71]$. DS subjects are characterized by lower serum levels of immunoglobulins IgM, while the other isotypes seem not to be affected [50, 51, $72,73]$. The impairment of the humoral immune system can lead to alterations in the responses to vaccinations [26, 29, 55]. Additionally, it can have an important impact on mucosal immunity, which is fundamental in the digestive and respiratory tracts for protection against infectious diseases, with possible impairment of mucosal IgA secretion rates in DS subjects [74].

\section{Innate immune system}

There are fewer reports evaluating the innate immune system in DS, as compared with the work done on the adaptive one.

Regarding the myeloid compartment of the innate immune system, one work has suggested that DS subjects have lower granulocyte counts, lower numbers of myeloid dendritic cells, and higher amounts of pro-inflammatory monocytes $\left(\mathrm{CD} 14^{\mathrm{dim}} \mathrm{CD} 16^{+}\right)$in peripheral blood as compared with controls [75]. This shift toward subsets associated with inflammation with an increase in inflammatory monocytes was further confirmed [56].

During normal aging, there is an increase in the proportions of natural killer (NK) cells [76, 77]. Regarding this compartment, results in DS are contradictory. First reports in DS, published in the early 1990s, testified of the existence of an expansion of cells with NK activity markers (CD16, CD56, CD57) $[47,78]$, which were however found functionally inefficient with a reduced NK activity [78]. In more recent reports, results were more inconsistent. Higher percentages of NK cells were described in three works [49, 56, 63], associated with an heightened state of activation [56], whereas absolute number was found normal [75] or even lower [79] in DS subjects as compared with controls. According to some authors, discrepancies could be partly attributed to the definitions used to define NK cells that did not fully discriminate NK cells from other subpopulations of $\mathrm{T}$ cells in the initial publications (no differentiation between CD3- and CD3+ cells).

\section{Inflammation}

Aging is characterized by a chronic, low-grade, and sterile inflammation, called "inflammaging," which has been directly associated with several age-related conditions [38, 80, 81]. The subclinical accumulation of pro-inflammatory factors progresses in parallel with immunosenescence (i.e., mainly a decrease in less-differentiated subsets associated with increase in terminally differentiated ones), and together, they form a vicious circle. In DS subjects, features of chronic 


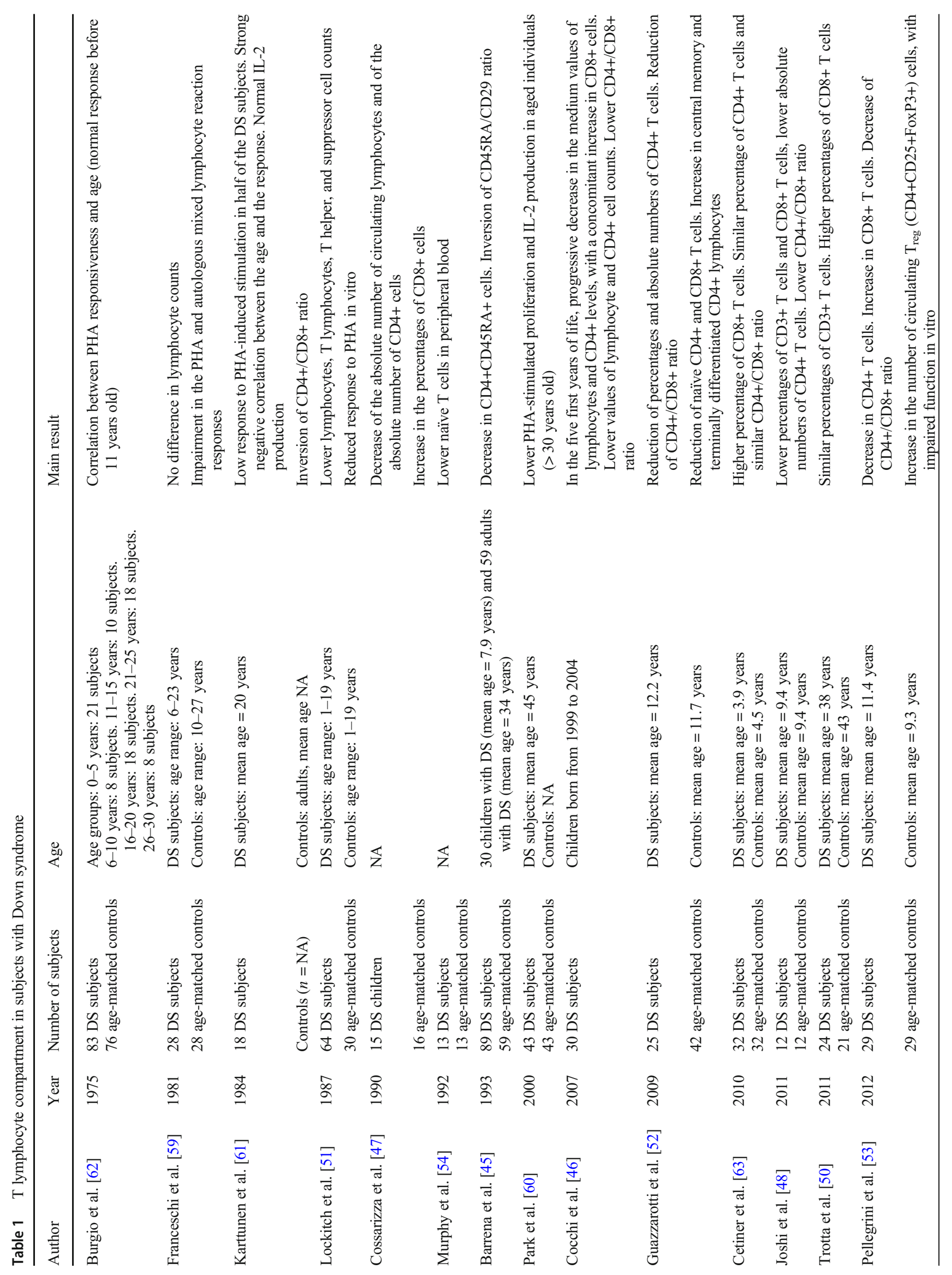


inflammation are strongly present. Individuals with DS have increased spontaneous circulating levels of pro-inflammatory cytokines, such as tumor necrosis factor (TNF)-alpha, interferon (IFN) gamma, or interleukin (IL)-6 and IL-1 $\beta$ [50, $82-87]$. This pro-inflammatory cytokine profile was confirmed in a recent meta-analysis performed by Zhang et al. on 19 studies in DS subjects, in which significantly increased circulating levels of TNF- $\alpha$, IFN $\gamma$, and IL- $1 \beta$ were demonstrated [88].

Recent works have shed light on the presence of a constant activation of the IFN response in individuals with DS [56, 57, $87,89]$. On a transcriptomic side, a consistent overexpression and hyperactivation of the interferon transcriptional response have been observed in different cell types [56, 57, 89], while on a protein side, an increased expression of IFN receptors and hypersensitivity to IFN-alpha were described [56]. The overexpression of IFN receptors (among which four of the six are encoded by genes located on chromosome 21 [90]), and especially type I IFN receptor subunit IFNAR1, is present across the entire immune system. In response to IFN stimulation, immune cells of DS individuals are hypersensitive and present a hyperactivation of cell type-specific downstream signaling cascades $[56,57]$. This increased interferon signaling has been linked to major circulating proteomic changes that are indicative of chronic auto-inflammation and which could fit in the scope of other inflammatory conditions (such as systemic lupus erythematosus or rheumatoid arthritis) or type I interferonopathies [87].

The chronic pro-inflammatory state observed in DS subjects is likely to greatly contribute to neurodegeneration. Inflammation is indeed considered as an important contributor to neurodegenerative disorders, such as Alzheimer's disease, which is highly prevalent in this population [91, 92]. Thus, combined measurement of $A \beta 40$ and $A \beta 42$ plasmatic levels with inflammatory molecules (such as TNF- $\alpha$ and IL-6) can be used as a strong predictor of prospective cognitive deterioration in DS individuals [83].

\section{Is the immune system in Down syndrome intrinsically deficient or victim of accelerated aging?}

As we have seen above, quantitative and qualitative alterations in all the compartments of the immune system in DS subjects have been well documented. The exact etiology of these alterations is however still debated, and the unanswered question is the following: is the immune system in DS primarily deficient or is it a victim of accelerated aging?

On one hand, some observations seem to be in line with the presence of an intrinsic defect $[71,79,93]$. Children with DS lack the vast expansion of T cells in the first years of life, and the lymphopenia observed later could be related to the impaired expansion of these cell lines in infancy. The impaired thymic output could be attributable partly to the altered thymic 


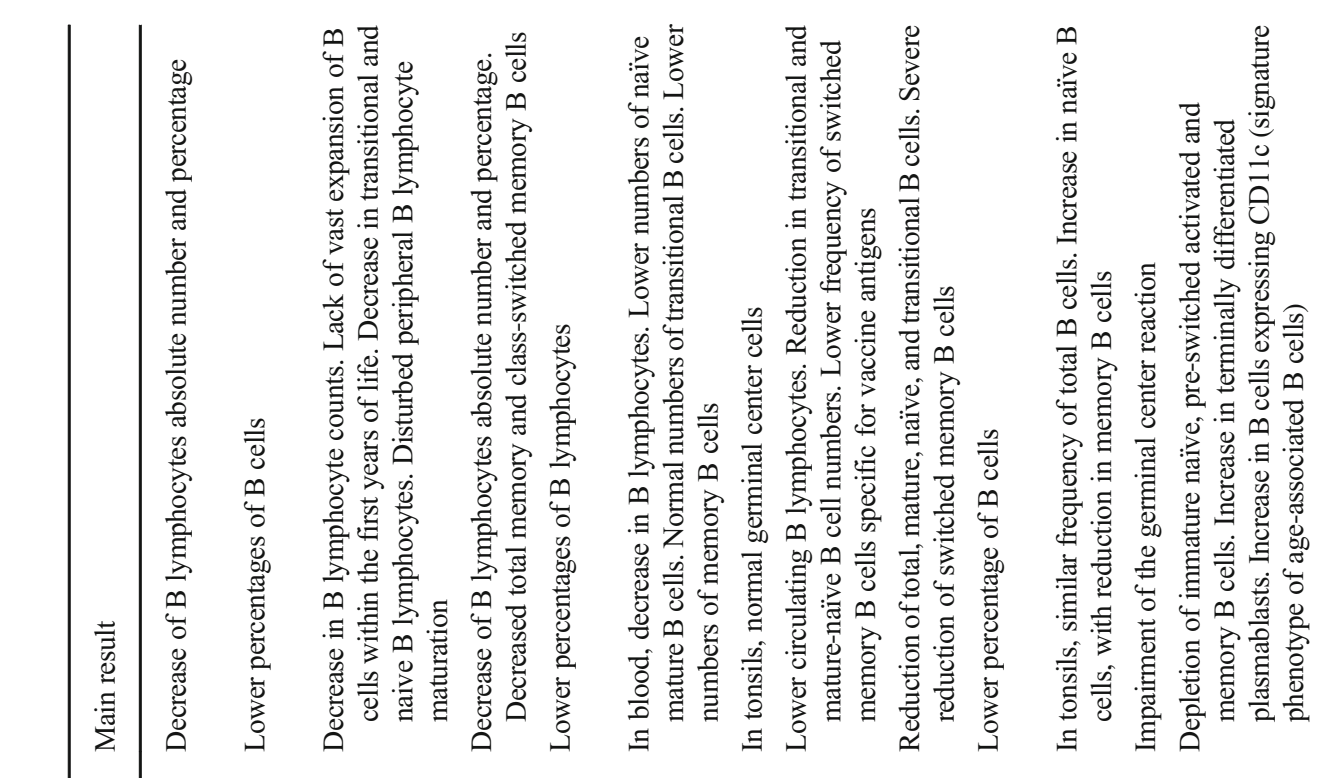

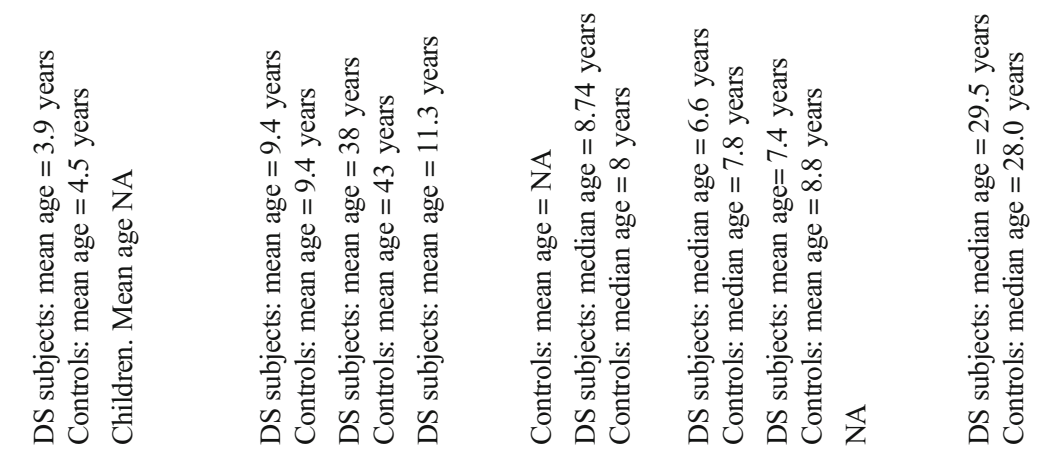

竞

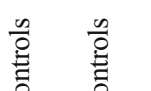

章言

䑸高

言

$n$
0

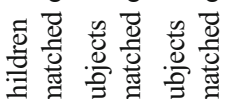

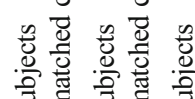

范

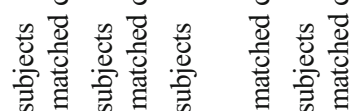

政

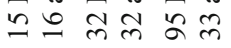

瓷

害产

密

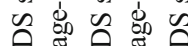



Iป 근

\%

느의 흐는

$\exists \cong$

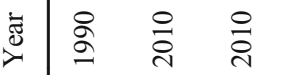

च)

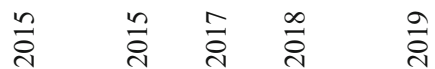

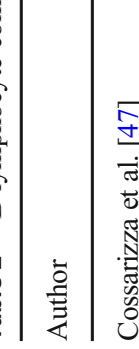

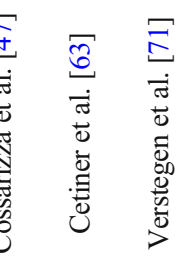

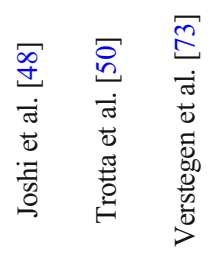

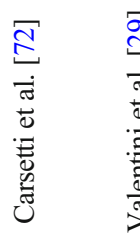

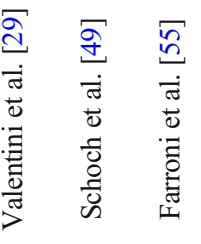

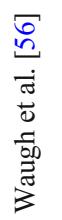


anatomy and function, present from the fetal stage onwards. To this regard, it should also be kept in mind that children with DS are at higher risk of thymectomy during cardiac surgery performed for congenital heart malformation. The information of the existence of a previous thymus resection is not always present in the studies, even though it has been demonstrated that thymectomy in this population can be associated with lower percentages of peripheral $\mathrm{T}$ cells [49].

On the other hand, the observed alterations in adaptive immunity in DS appear reminiscent of immunosenescence, with a phenomenon exacerbated with the age of the subjects [94]. For example, levels of T cells expressing TREC are significantly lower in DS individuals as compared with controls, and these levels correlate with the age of the subjects [58]. Moreover, a progressive decrease in the values of CD4+ $\mathrm{T}$ cells is observed in the first years of life of DS subjects [46]. From a functional point of view, lymphocyte responsiveness to phytohemagglutinin stimulation appears to be in the normal range during the first decade of life, but decreases progressively thereafter [61, 62]. Of particular importance is the obvious pro-inflammatory state observed in DS subjects, which is really similar to typical inflammaging observed during normal aging of the general population [56].

There is a likely possibility that both phenomena of intrinsic defect and accelerated aging are combined, like it seems to be the case in the mouse model of DS (Ts65Dn) [95]. In the animals, there is a clear decrease of the thymic output of immature $\mathrm{T}$ cells with a decline and involution of thymocyte progenitors, but at the same time, peripheral mature lymphocytes appear prematurely senescent and have a reduced capacity of proliferation after polyclonal stimulation [95]. In humans, this scenario appears possible and should be addressed in future studies, at the same time as some limits of the published works should be addressed too. Thus, one important limit of the work carried in DS immune system so far is the great heterogeneity of the individuals included in the studies regarding their chronological age. Observations published were performed on newborns, infants, children, or adults, and the comparability of these results is thus limited. Additionally, within the DS population itself, individuals are characterized by a large variability in terms of phenotype, with a high level of complexity in terms of co-morbidities, associated treatments, and social and cultural environments, which can all have a direct or indirect impact on the immune system.

\section{Accelerated immunosenescence in Down syndrome subjects: potential causes}

Aging is driven by interconnected cellular and molecular mechanisms, which have been gathered under the terms of hallmarks or pillars of aging $[96,97]$. These mechanisms are highly altered in DS subjects [17] and thus could participate in the acceleration of the aging process, especially in the immune system. Firstly, it is clear that there is a premature aging of the stem cell compartment in DS individuals, and especially of hematopoietic stem cells (HSC) with a significant decrease in circulating human stem and progenitor cells and a lack of HSC self-renewal [56, 98-100]. Secondly, alterations of metabolism have been described at different levels, with impairment of mitochondrial function and presence of chronic oxidative stress [101-103]. Thus, increased levels of endogenous oxygen species have been observed in lymphocytes from individuals with DS as compared with controls [104]. Additionally, higher levels of macromolecular damage are present in DS subjects, especially occurring on DNA molecules in lymphocytes [104-108], and an acceleration of telomere loss has been described in DS lymphocytes as well [109]. Finally, epigenetic patterns are modified, with differential blood DNA methylation signatures in DS individuals $[110,111]$ and age-related changes in the epigenetic machinery [112].

\section{Conclusions}

Individuals with DS display a spectrum of clinical and biological abnormalities, which are compatible with an important immune impairment. These disturbances are likely caused by the co-existence of two phenomena, with an intrinsic defect and precocious aging on one hand, and a clear phenomenon of accelerated aging on the other hand. The immune dysregulation affects key cell types, both in myeloid and lymphoid compartments, and is associated with a chronic state of inflammation. The dysregulation of immune responses and the inflammatory state are likely to greatly contribute to agerelated diseases and especially to neurodegeneration which is highly prevalent in this specific population [15]. Owing to the high level of co-morbidities present in DS individuals, there is an important need to develop and test novel therapeutic strategies $[17,56]$, in order to target and possibly tackle the phenomenon of accelerated aging in this population.

Funding information This study was supported by the European Union's Horizon2020 research and innovation program under the Marie Skłodowska-Curie grant agreement $n^{\circ} 675003$ ("PANINI: Physical Activity and Nutrition Influences In ageing”).

\section{Compliance with ethical standards}

Conflict of interest The authors declare that they have no conflict of interest.

Open Access This article is licensed under a Creative Commons Attribution 4.0 International License, which permits use, sharing, adaptation, distribution and reproduction in any medium or format, as long as you give appropriate credit to the original author(s) and the source, provide a link to the Creative Commons licence, and indicate if changes were made. The images or other third party material in this article are included 
in the article's Creative Commons licence, unless indicated otherwise in a credit line to the material. If material is not included in the article's Creative Commons licence and your intended use is not permitted by statutory regulation or exceeds the permitted use, you will need to obtain permission directly from the copyright holder. To view a copy of this licence, visit http://creativecommons.org/licenses/by/4.0/.

\section{References}

1. Roizen NJ, Patterson D (2003) Down's syndrome. Lancet 361: 1281-1289. https://doi.org/10.1016/S0140-6736(03)12987-X

2. de Graaf G, Buckley F, Skotko BG (2017) Estimation of the number of people with Down syndrome in the United States. Genet Med 19:439-447. https://doi.org/10.1038/gim.2016.127

3. Bittles AH, Glasson EJ (2004) Clinical, social, and ethical implications of changing life expectancy in Down syndrome. Dev Med Child Neurol 46:282-286

4. Glasson EJ, Jacques A, Wong K et al (2016) Improved survival in Down syndrome over the last 60 years and the impact of perinatal factors in recent decades. J Pediatr 169:214-220.e1. https://doi. org/10.1016/j.jpeds.2015.10.083

5. Leonard S, Bower C, Petterson B, Leonard H (2000) Survival of infants born with Down's syndrome: 1980-96. Paediatr Perinat Epidemiol 14:163-171

6. Yang Q, Rasmussen SA, Friedman JM (2002) Mortality associated with Down's syndrome in the USA from 1983 to 1997: a population-based study. Lancet 359:1019-1025

7. O’Leary L, Hughes-McCormack L, Dunn K, Cooper S-A (2018) Early death and causes of death of people with Down syndrome: a systematic review. J Appl Res Intellect Disabil 31:687-708. https://doi.org/10.1111/jar.12446

8. Strauss D, Eyman RK (1996) Mortality of people with mental retardation in California with and without Down syndrome, 1986-1991. Am J Ment Retard 100:643-653

9. Dyer CA, Sinclair AJ (1998) The premature ageing syndromes: insights into the ageing process. Age Ageing 27:73-80

10. Martin GM (1982) Syndromes of accelerated aging. Natl Cancer Inst Monogr 60:241-247

11. Martin GM (1978) Genetic syndromes in man with potential relevance to the pathobiology of aging. Birth Defects Orig Artic Ser 14:5-39

12. Patterson D, Cabelof DC (2012) Down syndrome as a model of DNA polymerase beta haploinsufficiency and accelerated aging. Mech Ageing Dev 133:133-137. https://doi.org/10.1016/j.mad. 2011.10.001

13. Zigman WB (2013) Atypical aging in Down syndrome. Dev Disabil Res Rev 18:51-67. https://doi.org/10.1002/ddrr.1128

14. Esbensen AJ (2010) Health conditions associated with aging and end of life of adults with Down syndrome. Int Rev Res Ment Retard 39:107-126. https://doi.org/10.1016/S0074-7750(10) 39004-5

15. Ballard C, Mobley W, Hardy J, Williams G, Corbett A (2016) Dementia in Down's syndrome. Lancet Neurol 15:622-636. https://doi.org/10.1016/S1474-4422(16)00063-6

16. Torr J, Strydom A, Patti P, Jokinen N (2010) Aging in Down syndrome: morbidity and mortality. Journal of Policy and Practice in Intellectual Disabilities 7:70-81. https://doi.org/10. 1111/j.1741-1130.2010.00249.x

17. Franceschi C, Garagnani P, Gensous N, Bacalini MG, Conte M, Salvioli S (2019) Accelerated bio-cognitive aging in Down syndrome: state of the art and possible deceleration strategies. Aging Cell 18:e12903. https://doi.org/10.1111/acel.12903
18. Horvath S, Garagnani P, Bacalini MG, Pirazzini C, Salvioli S, Gentilini D, di Blasio AM, Giuliani C, Tung S, Vinters HV, Franceschi C (2015) Accelerated epigenetic aging in Down syndrome. Aging Cell 14:491-495. https://doi.org/10.1111/acel. 12325

19. Obeid R, Hübner U, Bodis M, Geisel J (2016) Plasma amyloid beta 1-42 and DNA methylation pattern predict accelerated aging in young subjects with Down syndrome. NeuroMolecular Med 18:593-601. https://doi.org/10.1007/s12017-016-8413-y

20. Borelli V, Vanhooren V, Lonardi E, Reiding KR, Capri M, Libert C, Garagnani P, Salvioli S, Franceschi C, Wuhrer M (2015) Plasma N-glycome signature of Down syndrome. J Proteome Res 14:4232-4245. https://doi.org/10.1021/acs.jproteome. $5 \mathrm{~b} 00356$

21. Cole JH, Annus T, Wilson LR, Remtulla R, Hong YT, Fryer TD, Acosta-Cabronero J, Cardenas-Blanco A, Smith R, Menon DK, Zaman SH, Nestor PJ, Holland AJ (2017) Brain-predicted age in Down syndrome is associated with beta amyloid deposition and cognitive decline. Neurobiol Aging 56:41-49. https://doi.org/10. 1016/j.neurobiolaging.2017.04.006

22. Hilton JM, Fitzgerald DA, Cooper DM (1999) Respiratory morbidity of hospitalized children with Trisomy 21 . J Paediatr Child Health 35:383-386. https://doi.org/10.1046/j.1440-1754.1999. 00386.x

23. Mitwalli M, Wahba Y, Shaltout A, Gouida M (2018) Lymphocyte subgroups and recurrent infections in children with Down syndrome-a prospective case control study. Cent Eur J Immunol 43:248-254. https://doi.org/10.5114/ceji.2018.80042

24. Ram G, Chinen J (2011) Infections and immunodeficiency in Down syndrome. Clin Exp Immunol 164:9-16. https://doi.org/ 10.1111/j.1365-2249.2011.04335.x

25. Guffroy A, Dieudonné Y, Uring-Lambert B, Goetz J, Alembik Y, Korganow AS (2019) Infection risk among adults with Down syndrome: a two group series of 101 patients in a tertiary center. Orphanet J Rare Dis 14:15. https://doi.org/10.1186/s13023-0180989-x

26. Kusters MA, Jol-Van Der Zijde ECM, Gijsbers RHJM, de Vries E (2011) Decreased response after conjugated meningococcal serogroup $\mathrm{C}$ vaccination in children with Down syndrome. Pediatr Infect Dis J 30:818-819. https://doi.org/10.1097/INF. 0b013e31822233f9

27. Kusters MA, Bok VLA, Bolz WEA, Huijskens EGW, Peeters MF, de Vries E (2012) Influenza A/H1N1 vaccination response is inadequate in Down syndrome children when the latest cut-off values are used. Pediatr Infect Dis J 31:1284-1285. https://doi. org/10.1097/INF.0b013e3182737410

28. Kusters MA, Jol-van der Zijde CM, van Tol MJ et al (2011) Impaired avidity maturation after tetanus toxoid booster in children with Down syndrome. Pediatr Infect Dis J 30:357-359. https://doi.org/10.1097/INF.0b013e3181ff85a8

29. Valentini D, Marcellini V, Bianchi S, Villani A, Facchini M, Donatelli I, Castrucci MR, Marasco E, Farroni C, Carsetti R (2015) Generation of switched memory B cells in response to vaccination in Down syndrome children and their siblings. Vaccine 33:6689-6696. https://doi.org/10.1016/j.vaccine.2015. 10.083

30. da Rosa Utiyama SR, Nisihara RM, Nass FR, Oliveira NP, Fiedler PT, de Messias-Reason IT (2008) Autoantibodies in patients with Down syndrome: early senescence of the immune system or precocious markers for immunological diseases? J Paediatr Child Health 44:182-186. https://doi.org/10.1111/j.1440-1754.2007. 01229.x

31. Guaraldi F, Rossetto Giaccherino R, Lanfranco F et al (2017) Endocrine autoimmunity in Down's syndrome. Front Horm Res 48:133-146. https://doi.org/10.1159/000452912 
32. Karlsson B, Gustafsson J, Hedov G, Ivarsson SA, Anneren G (1998) Thyroid dysfunction in Down's syndrome: relation to age and thyroid autoimmunity. Arch Dis Child 79:242-245

33. Storm W (1990) Prevalence and diagnostic significance of gliadin antibodies in children with Down syndrome. Eur J Pediatr 149: 833-834

34. Fulop T, Larbi A, Dupuis G, le Page A, Frost EH, Cohen AA, Witkowski JM, Franceschi C (2017) Immunosenescence and inflamm-aging as two sides of the same coin: friends or foes? Front Immunol 8:1960. https://doi.org/10.3389/fimmu.2017. 01960

35. Franceschi C, Salvioli S, Garagnani P, de Eguileor M, Monti D, Capri M (2017) Immunobiography and the heterogeneity of immune responses in the elderly: a focus on Inflammaging and trained immunity. Front Immunol 8:982. https://doi.org/10.3389/ fimmu.2017.00982

36. Aiello A, Farzaneh F, Candore G, Caruso C, Davinelli S, Gambino CM, Ligotti ME, Zareian N, Accardi G (2019) Immunosenescence and its hallmarks: how to oppose aging strategically? A review of potential options for therapeutic intervention. Front Immunol 10:2247. https://doi.org/10.3389/fimmu. 2019.02247

37. Ventura MT, Casciaro M, Gangemi S, Buquicchio R (2017) Immunosenescence in aging: between immune cells depletion and cytokines up-regulation. Clinical and Molecular Allergy 15: 21. https://doi.org/10.1186/s12948-017-0077-0

38. Franceschi C, Bonafè M, Valensin S, Olivieri F, de Luca M, Ottaviani E, de Benedictis G (2000) Inflamm-aging. An evolutionary perspective on immunosenescence. Ann N Y Acad Sci 908:244-254

39. Thomas R, Wang W, Su D-M (2020) Contributions of age-related thymic involution to immunosenescence and inflammaging. Immun Ageing 17:2. https://doi.org/10.1186/s12979-020-0173-8

40. Goronzy JJ, Weyand CM (2019) Mechanisms underlying T cell ageing. Nat Rev Immunol 19:573-583. https://doi.org/10.1038/ s41577-019-0180-1

41. Elyahu Y, Hekselman I, Eizenberg-Magar I, et al (2019) Aging promotes reorganization of the CD4 $\mathrm{T}$ cell landscape toward extreme regulatory and effector phenotypes. Sci Adv 5:eaaw8330. https://doi.org/10.1126/sciadv.aaw8330

42. Goronzy JJ, Lee W-W, Weyand CM (2007) Aging and T-cell diversity. Exp Gerontol 42:400-406. https://doi.org/10.1016/j. exger.2006.11.016

43. Goronzy JJ, Weyand CM (2005) T cell development and receptor diversity during aging. Curr Opin Immunol 17:468-475. https:// doi.org/10.1016/j.coi.2005.07.020

44. Larbi A, Fulop T (2014) From "truly naïve" to "exhausted senescent" T cells: when markers predict functionality. Cytometry A 85:25-35. https://doi.org/10.1002/cyto.a.22351

45. Barrena MJ, Echaniz P, Garcia-Serrano C, Cuadrado E (1993) Imbalance of the CD4+ subpopulations expressing CD45RA and CD29 antigens in the peripheral blood of adults and children with Down syndrome. Scand J Immunol 38:323-326

46. Cocchi G, Mastrocola M, Capelli M et al (2007) Immunological patterns in young children with Down syndrome: is there a temporal trend? Acta Paediatr 96:1479-1482. https://doi.org/10.1111/ j.1651-2227.2007.00459.x

47. Cossarizza A, Monti D, Montagnani G, Ortolani C, Masi M, Zannotti M, Franceschi C (1990) Precocious aging of the immune system in Down syndrome: alteration of B lymphocytes, Tlymphocyte subsets, and cells with natural killer markers. Am J Med Genet Suppl 7:213-218

48. Joshi AY, Abraham RS, Snyder MR, Boyce TG (2011) Immune evaluation and vaccine responses in Down syndrome: evidence of immunodeficiency? Vaccine 29:5040-5046. https://doi.org/10. 1016/j.vaccine.2011.04.060
49. Schoch J, Rohrer TR, Kaestner M, Abdul-Khaliq H, Gortner L, Sester U, Sester M, Schmidt T (2017) Quantitative, phenotypical, and functional characterization of cellular immunity in children and adolescents with Down syndrome. J Infect Dis 215:16191628. https://doi.org/10.1093/infdis/jix168

50. Trotta MB, Serro Azul JB, Wajngarten M et al (2011) Inflammatory and immunological parameters in adults with Down syndrome. Immun Ageing 8:4. https://doi.org/10.1186/ 1742-4933-8-4

51. Lockitch G, Singh VK, Puterman ML, Godolphin WJ, Sheps S, Tingle AJ, Wong F, Quigley G (1987) Age-related changes in humoral and cell-mediated immunity in Down syndrome children living at home. Pediatr Res 22:536-540. https://doi.org/10.1203/ 00006450-198711000-00013

52. Guazzarotti L, Trabattoni D, Castelletti E, Boldrighini B, Piacentini L, Duca P, Beretta S, Pacei M, Caprio C, Vigan;ago A, di Natale B, Zuccotti GV, Clerici M (2009) T lymphocyte maturation is impaired in healthy young individuals carrying trisomy 21 (Down syndrome). Am J Intellect Dev Disabil 114:100 109. https://doi.org/10.1352/2009.114.100-109

53. Pellegrini FP, Marinoni M, Frangione V, Tedeschi A, Gandini V, Ciglia F, Mortara L, Accolla RS, Nespoli L (2012) Down syndrome, autoimmunity and T regulatory cells. Clin Exp Immunol 169:238-243. https://doi.org/10.1111/j.1365-2249.2012.04610.x

54. Murphy M, Epstein LB (1992) Down syndrome (DS) peripheral blood contains phenotypically mature CD3+TCR alpha, beta+ cells but abnormal proportions of TCR alpha, beta+, TCR gamma, delta+, and CD4+ CD45RA+ cells: evidence for an inefficient release of mature T cells by the DS thymus. Clin Immunol Immunopathol 62:245-251

55. Farroni C, Marasco E, Marcellini V, Giorda E, Valentini D, Petrini S, D'Oria V, Pezzullo M, Cascioli S, Scarsella M, Ugazio AG, de Vincentiis GC, Grimsholm O, Carsetti R (2018) Dysregulated miR-155 and miR-125b are related to impaired B-cell responses in Down syndrome. Front Immunol 9:2683. https://doi.org/10. 3389/fimmu.2018.02683

56. Waugh KA, Araya P, Pandey A et al (2019) Mass cytometry reveals global immune remodeling with multi-lineage hypersensitivity to type I interferon in Down syndrome. Cell Rep 29:18931908.e4. https://doi.org/10.1016/j.celrep.2019.10.038

57. Araya P, Waugh KA, Sullivan KD, Núñez NG, Roselli E, Smith KP, Granrath RE, Rachubinski AL, Enriquez Estrada B, Butcher ET, Minter R, Tuttle KD, Bruno TC, Maccioni M, Espinosa JM (2019) Trisomy 21 dysregulates $T$ cell lineages toward an autoimmunity-prone state associated with interferon hyperactivity. Proc Natl Acad Sci U S A 116:24231-24241. https://doi.org/ 10.1073/pnas.1908129116

58. Roat E, Prada N, Lugli E, Nasi M, Ferraresi R, Troiano L, Giovenzana C, Pinti M, Biagioni O, Mariotti M, di Iorio A, Consolo U, Balli F, Cossarizza A (2008) Homeostatic cytokines and expansion of regulatory $\mathrm{T}$ cells accompany thymic impairment in children with Down syndrome. Rejuvenation Res 11: 573-583. https://doi.org/10.1089/rej.2007.0648

59. Franceschi C, Licastro F, Chiricolo M et al (1981) Deficiency of autologous mixed lymphocyte reactions and serum thymic factor level in Down's syndrome. J Immunol 126:2161-2164

60. Park E, Alberti J, Mehta P, Dalton A, Sersen E, Schuller-Levis G (2000) Partial impairment of immune functions in peripheral blood leukocytes from aged men with Down's syndrome. Clin Immunol 95:62-69. https://doi.org/10.1006/clim.2000.4834

61. Karttunen R, Nurmi T, Ilonen J, Surcel HM (1984) Cell-mediated immunodeficiency in Down's syndrome: normal IL-2 production but inverted ratio of T cell subsets. Clin Exp Immunol 55:257-263

62. Burgio GR, Ugazio AG, Nespoli L, Marcioni AF, Bottelli AM, Pasquali F (1975) Derangements of immunoglobulin levels, phytohemagglutinin responsiveness and $\mathrm{T}$ and $\mathrm{B}$ cell markers in 
Down's syndrome at different ages. Eur J Immunol 5:600-603. https://doi.org/10.1002/eji.1830050904

63. Cetiner S, Demirhan O, Inal TC, Tastemir D, Sertdemir Y (2010) Analysis of peripheral blood T-cell subsets, natural killer cells and serum levels of cytokines in children with Down syndrome. Int J Immunogenet 37:233-237. https://doi.org/10.1111/j.1744-313X. 2010.00914.x

64. Fabris N, Mocchegiani E, Amadio L et al (1984) Thymic hormone deficiency in normal ageing and Down's syndrome: is there a primary failure of the thymus? Lancet 1:983-986

65. Larocca LM, Piantelli M, Valitutti S, Castellino F, Maggiano N, Musiani P (1988) Alterations in thymocyte subpopulations in Down's syndrome (trisomy 21). Clin Immunol Immunopathol 49:175-186

66. Murphy M, Lempert MJ, Epstein LB (1990) Decreased level of T cell receptor expression by Down syndrome (trisomy 21) thymocytes. Am J Med Genet Suppl 7:234-237

67. Musiani P, Valitutti S, Castellino F, Larocca LM, Maggiano N, Piantelli M (1990) Intrathymic deficient expansion of T cell precursors in Down syndrome. Am J Med Genet Suppl 7:219-224

68. Papadopoulos N, Simopoulos C, Venizelos J et al (2003) Fetal thymic medulla functional alterations in Down's syndrome. Minerva Med 94:181-185

69. Prada N, Nasi M, Troiano L, Roat E, Pinti M, Nemes E, Lugli E, Ferraresi R, Ciacci L, Bertoni D, Biagioni O, Gibertoni M, Cornia C, Meschiari L, Gramazio E, Mariotti M, Consolo U, Balli F, Cossarizza A (2005) Direct analysis of thymic function in children with Down's syndrome. Immun Ageing 2:4. https://doi.org/10. 1186/1742-4933-2-4

70. Frasca D, Blomberg BB (2009) Effects of aging on B cell function. Curr Opin Immunol 21:425-430. https://doi.org/10.1016/j. coi.2009.06.001

71. Verstegen RHJ, Kusters MAA, Gemen EFA, DE Vries E (2010) Down syndrome B-lymphocyte subpopulations, intrinsic defect or decreased T-lymphocyte help. Pediatr Res 67:563-569. https:// doi.org/10.1203/PDR.0b013e3181d4ecc1

72. Carsetti R, Valentini D, Marcellini V, Scarsella M, Marasco E, Giustini F, Bartuli A, Villani A, Ugazio AG (2015) Reduced numbers of switched memory B cells with high terminal differentiation potential in Down syndrome. Eur J Immunol 45:903-914. https://doi.org/10.1002/eji.201445049

73. Verstegen RHJ, Driessen GJ, Bartol SJW et al (2014) Defective Bcell memory in patients with Down syndrome. J Allergy Clin Immunol 134:1346-1353.e9. https://doi.org/10.1016/j.jaci.2014. 07.015

74. Chaushu S, Yefenof E, Becker A, Shapira J, Chaushu G (2002) Severe impairment of secretory Ig production in parotid saliva of Down syndrome individuals. J Dent Res 81:308-312. https://doi. org/10.1177/154405910208100504

75. Bloemers BLP, van Bleek GM, Kimpen JLL, Bont L (2010) Distinct abnormalities in the innate immune system of children with Down syndrome. J Pediatr 156:804-809, 809.e1-809.e5. https://doi.org/10.1016/j.jpeds.2009.12.006

76. Camous X, Pera A, Solana R, Larbi A (2012) NK cells in healthy aging and age-associated diseases. J Biomed Biotechnol 2012: 195956-195958. https://doi.org/10.1155/2012/195956

77. Gounder SS, Abdullah BJJ, Radzuanb NEIBM, Zain FDBM, Sait NBM, Chua C, Subramani B (2018) Effect of aging on NK cell population and their proliferation at ex vivo culture condition. Anal Cell Pathol (Amst) 2018:1-6. https://doi.org/10.1155/2018/ 7871814

78. Cossarizza A, Ortolani C, Forti E, Montagnani G, Paganelli R, Zannotti M, Marini M, Monti D, Franceschi C (1991) Agerelated expansion of functionally inefficient cells with markers of natural killer activity in Down's syndrome. Blood 77:12631270
79. de Hingh YCM, van der Vossen PW, Gemen EFA, Mulder AB, Hop WCJ, Brus F, de Vries E (2005) Intrinsic abnormalities of lymphocyte counts in children with Down syndrome. J Pediatr 147:744-747. https://doi.org/10.1016/j.jpeds.2005.07.022

80. Franceschi C, Capri M, Monti D, Giunta S, Olivieri F, Sevini F, Panourgia MP, Invidia L, Celani L, Scurti M, Cevenini E, Castellani GC, Salvioli S (2007) Inflammaging and antiinflammaging: a systemic perspective on aging and longevity emerged from studies in humans. Mech Ageing Dev 128:92105. https://doi.org/10.1016/j.mad.2006.11.016

81. Franceschi C, Campisi J (2014) Chronic inflammation (inflammaging) and its potential contribution to age-associated diseases. J Gerontol A Biol Sci Med Sci 69(Suppl 1):S4-S9. https://doi.org/10.1093/gerona/glu057

82. Carta MG, Serra P, Ghiani A, Manca E, Hardoy MC, del Giacco GS, Diaz G, Carpiniello B, Manconi PE (2002) Chemokines and pro-inflammatory cytokines in Down's syndrome: an early marker for Alzheimer-type dementia? Psychother Psychosom 71:233236. https://doi.org/10.1159/000063649

83. Iulita MF, Ower A, Barone C, Pentz R, Gubert P, Romano C, Cantarella RA, Elia F, Buono S, Recupero M, Romano C, Castellano S, Bosco P, di Nuovo S, Drago F, Caraci F, Cuello AC (2016) An inflammatory and trophic disconnect biomarker profile revealed in Down syndrome plasma: relation to cognitive decline and longitudinal evaluation. Alzheimers Dement 12: 1132-1148. https://doi.org/10.1016/j.jalz.2016.05.001

84. Nateghi Rostami M, Douraghi M, Miramin Mohammadi A, Nikmanesh B (2012) Altered serum pro-inflammatory cytokines in children with Down's syndrome. Eur Cytokine Netw 23:64-67. https://doi.org/10.1684/ecn.2012.0307

85. Rodrigues R, Debom G, Soares F, Machado C, Pureza J, Peres W, de Lima Garcias G, Duarte MF, Schetinger MRC, Stefanello F, Braganhol E, Spanevello R (2014) Alterations of ectonucleotidases and acetylcholinesterase activities in lymphocytes of Down syndrome subjects: relation with inflammatory parameters. Clin Chim Acta 433:105-110. https://doi.org/10. 1016/j.cca.2014.03.002

86. Zaki ME, El-Bassyouni HT, Tosson AMS et al (2017) Coenzyme Q10 and pro-inflammatory markers in children with Down syndrome: clinical and biochemical aspects. J Pediatr 93:100-104. https://doi.org/10.1016/j.jped.2016.04.012

87. Sullivan KD, Evans D, Pandey A, Hraha TH, Smith KP, Markham N, Rachubinski AL, Wolter-Warmerdam K, Hickey F, Espinosa JM, Blumenthal T (2017) Trisomy 21 causes changes in the circulating proteome indicative of chronic autoinflammation. Sci Rep 7:14818. https://doi.org/10.1038/s41598-017-13858-3

88. Zhang Y, Che M, Yuan J, Yu Y, Cao C, Qin XY, Cheng Y (2017) Aberrations in circulating inflammatory cytokine levels in patients with Down syndrome: a meta-analysis. Oncotarget 8:8448984496. https://doi.org/10.18632/oncotarget.21060

89. Sullivan KD, Lewis HC, Hill AA, Pandey A, Jackson LP, Cabral JM, Smith KP, Liggett LA, Gomez EB, Galbraith MD, DeGregori J, Espinosa JM (2016) Trisomy 21 consistently activates the interferon response. Elife 5. https://doi.org/10.7554/eLife.16220

90. de Weerd NA, Nguyen T (2012) The interferons and their receptors-distribution and regulation. Immunol Cell Biol 90: 483-491. https://doi.org/10.1038/icb.2012.9

91. Wilcock DM (2012) Neuroinflammation in the aging Down syndrome brain; lessons from Alzheimer's disease. Curr Gerontol Geriatr Res 2012:170276-170210. https://doi.org/10.1155/2012/ 170276

92. Wilcock DM, Hurban J, Helman AM, Sudduth TL, McCarty KL, Beckett TL, Ferrell JC, Murphy MP, Abner EL, Schmitt FA, Head E (2015) Down syndrome individuals with Alzheimer's disease have a distinct neuroinflammatory phenotype compared to 
sporadic Alzheimer's disease. Neurobiol Aging 36:2468-2474. https://doi.org/10.1016/j.neurobiolaging.2015.05.016

93. Kusters MAA, Gemen EFA, Verstegen RHJ, Wever PC, de Vries E (2010) Both normal memory counts and decreased naive cells favor intrinsic defect over early senescence of Down syndrome $T$ lymphocytes. Pediatr Res 67:557-562. https://doi.org/10.1203/ PDR.0b013e3181d4eca3

94. Kusters MA, Verstegen RH, de Vries E (2011) Down syndrome: is it really characterized by precocious immunosenescence? Aging Dis 2:538-545

95. Lorenzo LPE, Shatynski KE, Clark S, Yarowsky PJ, Williams MS (2013) Defective thymic progenitor development and mature Tcell responses in a mouse model for Down syndrome. Immunology 139:447-458. https://doi.org/10.1111/imm.12092

96. Kennedy BK, Berger SL, Brunet A, Campisi J, Cuervo AM, Epel ES, Franceschi C, Lithgow GJ, Morimoto RI, Pessin JE, Rando TA, Richardson A, Schadt EE, Wyss-Coray T, Sierra F (2014) Geroscience: linking aging to chronic disease. Cell 159:709713. https://doi.org/10.1016/j.cell.2014.10.039

97. López-Otín C, Blasco MA, Partridge L, Serrano M, Kroemer G (2013) The hallmarks of aging. Cell 153:1194-1217. https://doi. org/10.1016/j.cell.2013.05.039

98. Cairney CJ, Sanguinetti G, Ranghini E, Chantry AD, Nostro MC, Bhattacharyya A, Svendsen CN, Keith WN, Bellantuono I (2009) A systems biology approach to Down syndrome: identification of Notch/Wnt dysregulation in a model of stem cells aging. Biochim Biophys Acta 1792:353-363. https://doi.org/10.1016/j.bbadis. 2009.01.015

99. Liu B, Filippi S, Roy A, Roberts I (2015) Stem and progenitor cell dysfunction in human trisomies. EMBO Rep 16:44-62. https:// doi.org/10.15252/embr.201439583

100. Adorno M, Sikandar S, Mitra SS, Kuo A, Nicolis di Robilant B, Haro-Acosta V, Ouadah Y, Quarta M, Rodriguez J, Qian D, Reddy VM, Cheshier S, Garner CC, Clarke MF (2013) Usp16 contributes to somatic stem-cell defects in Down's syndrome. Nature 501:380-384. https://doi.org/10.1038/nature12530

101. Arbuzova S, Hutchin T, Cuckle H (2002) Mitochondrial dysfunction and Down's syndrome. Bioessays 24:681-684. https://doi. org/10.1002/bies.10138

102. Caracausi M, Ghini V, Locatelli C, Mericio M, Piovesan A, Antonaros F, Pelleri MC, Vitale L, Vacca RA, Bedetti F, Mimmi MC, Luchinat C, Turano P, Strippoli P, Cocchi G (2018) Plasma and urinary metabolomic profiles of Down syndrome correlate with alteration of mitochondrial metabolism. Sci Rep 8:2977. https://doi.org/10.1038/s41598-018-20834-y

103. Conte M, Ostan R, Fabbri C, Santoro A, Guidarelli G, Vitale G, Mari D, Sevini F, Capri M, Sandri M, Monti D, Franceschi C, Salvioli S (2018) Human aging and longevity are characterized by high levels of mitokines. J Gerontol A Biol Sci Med Sci 74:600 607. https://doi.org/10.1093/gerona/gly153
104. Zana M, Szécsényi A, Czibula A, Bjelik A, Juhász A, Rimanóczy Á, Szabó K, Vetró Á, Szücs P, Várkonyi Á, Pákáski M, Boda K, Raskó I, Janka Z, Kálmán J (2006) Age-dependent oxidative stress-induced DNA damage in Down's lymphocytes. Biochem Biophys Res Commun 345:726-733. https://doi.org/10.1016/j. bbrc.2006.04.167

105. Franceschi C, Monti D, Scarfi MR et al (1992) Genomic instability and aging. Studies in centenarians (successful aging) and in patients with Down's syndrome (accelerated aging). Ann N Y Acad Sci 663:4-16

106. Maluf SW, Erdtmann B (2001) Genomic instability in Down syndrome and Fanconi anemia assessed by micronucleus analysis and single-cell gel electrophoresis. Cancer Genet Cytogenet 124:7175

107. Morawiec Z, Janik K, Kowalski M, Stetkiewicz T, Szaflik J, Morawiec-Bajda A, Sobczuk A, Blasiak J (2008) DNA damage and repair in children with Down's syndrome. Mutat Res 637: 118-123. https://doi.org/10.1016/j.mrfmmm.2007.07.010

108. Tiano L, Littarru GP, Principi F, Orlandi M, Santoro L, Carnevali $\mathrm{P}$, Gabrielli O (2005) Assessment of DNA damage in Down syndrome patients by means of a new, optimised single cell gel electrophoresis technique. Biofactors 25:187-195

109. Vaziri H, Schächter F, Uchida I, Wei L, Zhu X, Effros R, Cohen D, Harley CB (1993) Loss of telomeric DNA during aging of normal and trisomy 21 human lymphocytes. Am J Hum Genet 52:661-667

110. Kerkel K, Schupf N, Hatta K, Pang D, Salas M, Kratz A, Minden M, Murty V, Zigman WB, Mayeux RP, Jenkins EC, Torkamani A, Schork NJ, Silverman W, Croy BA, Tycko B (2010) Altered DNA methylation in leukocytes with trisomy 21. PLoS Genet 6: e1001212. https://doi.org/10.1371/journal.pgen.1001212

111. Bacalini MG, Gentilini D, Boattini A, Giampieri E, Pirazzini C, Giuliani C, Fontanesi E, Scurti M, Remondini D, Capri M, Cocchi G, Ghezzo A, del Rio A, Luiselli D, Vitale G, Mari D, Castellani G, Fraga M, di Blasio AM, Salvioli S, Franceschi C, Garagnani P (2015) Identification of a DNA methylation signature in blood cells from persons with Down syndrome. Aging (Albany NY) 7: 82-96. https://doi.org/10.18632/aging. 100715

112. Ciccarone F, Valentini E, Malavolta M, Zampieri M, Bacalini MG, Calabrese R, Guastafierro T, Reale A, Franceschi C, Capri M, Breusing N, Grune T, Moreno-Villanueva M, Bürkle A, Caiafa P (2018) DNA hydroxymethylation levels are altered in blood cells from Down syndrome persons enrolled in the MARK-AGE project. J Gerontol A Biol Sci Med Sci 73:737-744. https://doi. org/10.1093/gerona/glx198

Publisher's note Springer Nature remains neutral with regard to jurisdictional claims in published maps and institutional affiliations. 